\title{
A Portaria 1.129/2017 e o impacto na fiscalização do trabalho em condições análogas à de escravo no Brasil contemporâneo
}

\author{
Ordinance 1,129/2017 and the Impact on the supervision \\ of Labor in Conditions Analogue to Slave in Contemporary Brazil
}

Ordenanza 1.129/2017 y el impacto en la supervisión del trabajo en
condiciones analógicas para esclavar en el Brasil Contemporáneo

Carine Azevedo Saraiva

Universidade Lasalle

ReSumo O presente estudo tem como objetivo analisar a atual situação de trabalhadores brasileiros que estão diariamente expostos a condições de trabalho degradantes e vêm exercendo suas funções em ambientes de trabalho cujo cenário é de escravidão. A partir disso, faz-se necessário entender como as autoridades têm realizado a fiscalização de tais locais de trabalho e após a implantação da Portaria 1.129/2017 observar, além de seus impactos, os movimentos feitos a fim de erradicar o problema da exploração da mão de obra atual, atentando para o controle exercido pela Administração Pública por meio do Poder de Polícia. Além disso, é de extrema importância compreender sua eficácia frente às mudanças e medidas que visam erradicar a exposição do trabalhador em situações precárias e abusivas que potencializam as condições de escravidão no ambiente de trabalho. Por fim, a percepção dos efeitos e mudanças da Portaria 1.129/2017 na regulamentação da fiscalização do trabalho escravo contemporâneo, considerando a sua consequente revogação e implantação de nova Portaria 1.293/2017, ainda em vigor.

Palavras-chave: Administração Pública. Poder de polícia. Trabalho escravo conTEMPORÂNEO. PoRTARIA 1.129/2017.

ABSTRaCr This study aims to analyze the current situation of Brazilian workers who are daily exposed to degrading working conditions and have been performing their functions in work environments whose scenario is slavery. From this, it is necessary to understand how the authorities have carried out the supervision of such workplaces and after the implementation of Ordinance 1.129/2017 observe, in addition to its impacts, the movements made in order to eradicate the problem of exploitation of the current labor force, in view of 
the control exercised by the Public Administration through the Police Power. Moreover, it is extremely important to understand its effectiveness in the face of changes and measures aimed at eradicating worker's exposure in precarious and abusive situations that enhance the conditions of slavery in the work environment. Finally, the perception of the effects and changes of Ordinance 1,129/2017 on the regulation of the supervision of contemporary slave labor. In addition, it is extremely important to understand its effectiveness in the face of changes and measures aimed at eradicating worker exposure in precarious and abusive situations that enhance the conditions of slavery in the workplace. Finally, the perception of the effects and changes of Ordinance 1.129/2017 in the regulation of the supervision of contemporary slave labor, considering its consequent repeal and implementation of new Ordinance 1.293/2017, still in force.

Keywords: Public administration. Police Power. Contemporary Slave labor. OrDINANCE $1.129 / 2017$.

RESUMEN El presente estudio tiene como objetivo analizar la situación actual de los trabajadores brasileños que están expuestos diariamente a condiciones laborales degradantes $\mathrm{y}$ han estado ejerciendo sus funciones en entornos laborales cuyo escenario es de esclavitud. A partir de esto, es necesario comprender cómo las autoridades han llevado a cabo la inspección de dichos lugares de trabajo y después de la implementación de la Ordenanza 1.129/2017 observar, además de sus impactos, los movimientos realizados para erradicar el problema de la explotación de manos. del trabajo actual, prestando atención al control ejercido por la Administración Pública a través del Poder Policial. Además, es extremadamente importante comprender su efectividad frente a los cambios y las medidas que apuntan a erradicar la exposición de los trabajadores en situaciones precarias y abusivas que mejoran las condiciones de esclavitud en el entorno laboral. Finalmente, la percepción de los efectos y cambios de la Ordenanza 1.129/2017 en la regulación de la inspección del trabajo esclavo contemporáneo, considerando su consiguiente revocación e implementación de una nueva Ordenanza 1.293/2017, aún vigente.

Palabras Clave: Administración pública. Poder policial. Trabajo esclavo contemPORÂNEO. ORDENANZA 1.129/2017.

\section{INTRODUÇÃO}

Em 13 de outubro de 2017, foi implantada pelo Presidente da República, Michel Temer, a Portaria de $n^{0} 1.127$, contendo novas regras para a fiscalização e erradicação do trabalho escravo contemporâneo. Com a sua publicação, houve uma enxurrada de críticas aos novos conceitos e formas de combate ao trabalho escravo, que consideravam como um retrocesso as alterações para a continuidade da busca da extinção das condições de trabalho análogas às de escravo.

Considerada por muitos como um regresso de aproximadamente 200 anos e, até mesmo, de que as novas formas de fiscalização e intervenção do trabalho escravo retrocederam para o século XIX, a nova Portaria trouxe diversos obstáculos que dificultaram a caracte- 
rização do trabalho escravo e o controle exercido para a erradicação de diversas situações que deixam inúmeros trabalhadores expostos e em ambientes de escravidão, em pleno século XXI. Cenários de maus-tratos, jornadas de trabalho exaustivas, instalações precárias, trabalho forçado por dívida, condições de higiene inadequadas e retenção de documentos foram, de maneira agressiva, desconsiderados pela nova Portaria, que passou a exigir, para que qualquer uma dessas condições fosse apontada de fato como uma situação de trabalho escravo, um obstáculo a mais, como a restrição do direito de ir e vir ou o consentimento do trabalhador.

A partir de tais mudanças, e conforme o entendimento de alguns autores, o impacto causado trouxe graves consequências para a Administração Pública na medida em que influenciaram e dificultaram a fiscalização desses ambientes de trabalho, obstaculizando o papel do Poder de Polícia ao exercer a tentativa de controle e erradicação de situações de trabalho em condições análogas à de escravo no Brasil contemporâneo.

Com tamanha involução e o declínio gerado pela Portaria 1.129/2017, fez-se necessária nova análise e a aplicação de medidas que pudessem interromper as suas consequências. Para tanto, buscou-se no Poder Judiciário a apreciação das mudanças provenientes da nova Portaria e a consequente decisão relatada pela Ministra Rosa Weber, na ADPF 489 de 2017, que por sua vez teve papel fundamental na suspensão liminar dos seus efeitos e na consequente implantação da ainda vigente Portaria 1.293, de 28 de dezembro de 2017 , corroborando a fiscalização eficaz do trabalho escravo, entendendo que:

A portaria foi editada com o inconfessável propósito de inviabilizar uma das mais importantes políticas públicas adotadas no Brasil para a proteção e promoção da dignidade humana e dos direitos fundamentais: a política de combate ao trabalho escravo (ADPF 489, 2017).

Diante de tais fatos, viu-se a necessidade de executar forças tarefas com o intuito de erradicar a exploração do trabalhador exposto às condições de trabalho escravo na atualidade a fim de trazer de volta a sua dignidade e liberdade como bens jurídicos a serem protegidos pela legislação.

\section{A origem do trabalho escravo no Brasil}

O trabalho escravo originou-se mais precisamente no século XVI, quando o escravo era considerado como "coisa", sendo este associado a animais e não a pessoa humana. ${ }^{1}$ Nessa época, ao adquirir suas terras, os "homens ricos" partiam na busca de escravos, conservando a ideia de que quanto mais homens trabalhando em suas terras, tanto mais riquezas teriam, além de maior afirmação nas colônias, frente aos demais proprietários. "O morador honrado era o que podia sustentar sua família sem desempenhar qualquer trabalho, e tanto mais rico seria, quanto mais escravos possuísse" (RONALDO VAINFAS -, 1986).

Nessa época, e ainda distantes de perceber a escravidão como fato social, a associação feita era a de que o ato de trabalhar e a escravidão caminhavam juntos, e o escravo utilizado

VAINFAS, Ronaldo. IDEOLOGIA E ESCRAVIDÃO. Os letrados e a sociedade escravista no Brasil Colonial. Petrópolis, 1986. 
no trabalho pesado, sem direitos a reclamar era tido como coisa, ou pior, considerado como um pecador e penitente, e deveria pagar por seus pecados e, dessa forma, necessariamente e por ser completamente leigo e não possuir o menor recurso, tampouco qualquer opção, a não ser a de exercer o trabalho que lhe era imposto, era forçado a desempenhar o trabalho pesado em troca de moradia, comida e até mesmo de sua sobrevivência.

Considerando que trabalho era tarefa de escravos, estes o faziam sem motivação mercantil, nem ao menos com a intenção de crescimento patrimonial, mas sim para garantir o seu sustento com mantimentos, vestimenta e moradia. A riqueza produzida a partir do trabalho escravo era destinada aos seus senhorios ricos, donos das terras, que lucravam com absolutamente tudo, sem propiciar ao trabalhador escravo a menor condição de existência, acreditando que seu destino era a execução do trabalho pesado e não deveria este lucrar com a sua prática. ${ }^{2}$ Negros, em sua maioria, podendo ser homens ou mulheres, ladinos ou boçais, seja na plantação ou dedicando-se a algum oficio específico, cada um possuía determinada função imposta e essa deveria ser praticada sem pausas, sem descansos, pois se acreditava que ao impor trabalho em tempo intermitente se estaria impedindo o escravo de tentar se livrar de seu senhor, evitando que se tornasse rebelde e mantendo o domínio de quem era o seu dono. "O trabalho, pois é o melhor remédio para trazer os servos sujeitos e bem domados. (...) O trabalho do servo é descanso do senhor; porque enquanto o servo fatigado do serviço anela e aspira a algum repouso, não cuida, nem trata de se rebelar contra seu senhor" (JORGE BENCI, 1977).

Registra-se, dessa forma, que o trabalho escravo teve início há anos, de forma degradante, quando trabalhadores negros, em sua maioria, não tinham poder de suas próprias vidas, necessitando exercer o trabalho forçado a que lhes eram impostos, a fim de obter uma melhor condição de vida. Além de estarem expostos ao trabalho pesado e sem pausas, não tinham acesso à educação, pois se acreditava que o conhecimento poderia ser o motivo de uma rebeldia dos trabalhadores. Ao violar os básicos direitos humanos e atentar contra a dignidade da pessoa humana trabalhadora, os senhorios forçavam os seus servos a trabalhar incansavelmente, os restringiam de locomoções, vigiavam ostensivamente seus locais de trabalho, ameaçavam com sanção e aplicação de castigo a quem desobedecesse além de exigir de seus trabalhadores uma jornada de trabalho física e mental de extrema intensidade com condições absurdamente humilhantes. ${ }^{3}$

Desde então, pessoas tidas como escravos por senhores que faziam parte do poder exerciam funções degradantes sem a menor condição humana de trabalho, com atividades pesadas e nenhum descanso, físico ou mental. Além disso, os locais de trabalho eram considerados desumanos, sem estruturas, banheiros ou refeitórios, assistência médica ou a menor condição de moradia a essas pessoas. ${ }^{4}$ Ainda, eram submetidos a castigos cruéis e, até mesmo à morte quando desobedecessem às ordens de seus senhores, e vendidos como mercadorias a outros homens ricos, donos de terras, que também faziam parte do poder

\footnotetext{
IDEM.
}

3 VAINFAS, Ronaldo. IDEOLOGIA E ESCRAVIDÃO. Os letrados e a sociedade escravista no Brasil Colonial. Petrópolis, 1986.

4 SILVA, Rute Mikaele Pachedo da. O TRABALHO ESCRAVO NO BRASIL E A EMENDA CONSTITUCIONAL No. 81/2014, 2016, p. 74. Trabalho de Conclusão de Curso (Mestrado em Direito). Universidade Federal de Pernambuco, 2016 [Orientador: Adriano Nascimento Silva]. 
e negociavam os escravos, situações que os levavam a diversas tentativas de fuga, como Machado de Assis, em sua obra "Pai contra mãe", descreve:

Há meio século, os escravos fugiam com frequência. Eram muitos, e nem todos gostavam da escravidão. Sucedia ocasionalmente apanharem pancada, e nem todos gostavam de apanhar pancada. Grande parte era apenas repreendida (...) (ASSIS, 1906, p. 4).

Como se não bastasse tamanha crueldade muitos desses homens escravos eram impedidos de ver sua família, se tornavam prisioneiros para que exercessem seus trabalhos sem o risco das fugas ou rebeldias e, quando já não serviam, eram descartados.

\section{$1.1 O$ trabalho escravo contemporâneo sob a ótica da Constituição Fe- deral de 1988}

Os direitos humanos fundamentais garantidos pela Constituição Federal de 1988, ou os direitos sociais, garantem, na teoria, os direitos básicos para a vida e a dignidade humanas, assegurando às pessoas o direito à educação, à alimentação, à saúde, ao trabalho, à moradia e ao lazer. As sociedades foram criadas e cresceram com a perspectiva de que $\mathrm{o}$ que está previsto e garantido por Lei seja de fato aplicado a todas as pessoas que dela fazem parte, garantindo, ainda, a liberdade e a autonomia, a fim de obter um Estado democrático com a interação e proteção de todos.

Todos os direitos elencados têm como fundamento a dignidade da pessoa humana e são considerados como direitos fundamentais para a construção da vida em sociedade. A Constituição Federal de 1988, em seu artigo $5^{\circ} .{ }^{5}$ garante a todos, de forma igual, os direitos necessários para as necessidades humanas básicas.

Artigo $5^{\circ}$. Todos são iguais perante a lei, sem distinção de qualquer natureza, garantindo-se aos brasileiros e aos estrangeiros residentes no País a inviolabilidade do direito à vida, à liberdade, à igualdade, à segurança e à propriedade, nos termos seguintes $[\ldots]$.

Quando se fala em escravidão contemporânea, a Constituição Federal garante de forma pontual a sua proibição, mesmo que o tema seja tratado de forma descompromissada por grande parte da população e, ainda, assegura a possibilidade de atribuir sanção àqueles que praticarem qualquer ato que deixe a vida de alguém exposta às condições de escravidão, conforme está exposto no Código Penal brasileiro, em seu artigo $149,{ }^{6}$ que explica:

Artigo 149. Reduzir alguém a condição análoga à de escravo, quer submetendo-o a trabalhos forçados ou a jornada exaustiva, quer sujeitando-o a condições degradantes de trabalho, quer restringindo, por qualquer meio, sua locomoção em razão de dívida contraída com o empregador ou preposto:

Pena - reclusão, de dois a oito anos, e multa, além da pena correspondente à violência.

\footnotetext{
5 Constituição da República, de 5/10/1988.

6 Lei 2.848 , de 7/12/1940.
} 
Com o surgimento do Estado moderno, e a consequente expectativa de que a pobreza e a exclusão social deixariam de fazer parte da sociedade, após diversas reivindicações e lutas sociais que trouxeram a garantia de melhor qualidade de vida das pessoas, gerou uma maior possibilidade da extinção de situações de trabalho em condições análogas à de escravo no Brasil.

A abolição da escravatura, a partir da Lei Áurea de 13 de maio de 1888, em nada colaborou para que os escravos libertos tivessem acesso à terra, à moradia, ou qualquer condição digna de produção e sobrevivência, impedindo o surgimento da igualdade entre os homens. ${ }^{7}$ A mensurada Lei proibiu legalmente o regime de escravidão, mas, como podemos perceber nos dias atuais, não há a erradicação das práticas escravagistas existentes nos períodos colonial e imperial, uma vez que se repetem na atualidade com inovações na sua nomenclatura, considerados por vezes como "trabalho forçado", "trabalho degradante" ou "servidão por dívida" entre tantos outros adjetivos, não chamando a atenção para a real situação de trabalho escravo existente no Brasil contemporâneo. ${ }^{8}$

Darcy Ribeiro afirma que "o Brasil, último país a acabar com a escravidão, tem uma perversidade intrínseca na sua herança, que torna a nossa classe dominante enferma de desigualdade, de descaso".

A partir disso, podemos observar que há uma exploração em demasia em relação à força de trabalho na atualidade, consideradas, inclusive, como formas renovadas de escravagismo e, ainda, como a prática do psicoterror realizado por seus empregadores por meio da prática de gestão por injúria acometida em uma nação dependente e que, ainda sem se dar conta, exerce funções de trabalho escravo por absoluta necessidade, o que gera um problema social atualmente enfrentado, ainda que legalmente proibido, como Lopes menciona:

\footnotetext{
Apenas alterou-se a forma de se escravizar, do escravo negro do regime colonial [e imperial] legitimado pelas leis regentes no país, para o escravo sem distinção de cor, raça, religião. É a subalternidade do trabalhador que está em jogo para a ampliação do processo produtivo e ampliação do capital nas mãos de poucos. O homem livre como sujeito tem agora a valorização da sua força de trabalho baseada em salário. No entanto, não é ele quem determina o valor de sua força de trabalho; tal preço é subordinado à imposição dos donos de propriedade (LOPES, 2009, p. 40).
}

A escravidão contemporânea existente na atualidade ainda possui traços do modelo de escravidão do Brasil colonial, afinal, os trabalhadores escravos ainda permanecem residindo nos locais de trabalho pelo tempo necessário, ou, enquanto houver trabalho a ser exercido, além do contínuo uso da mão de obra ilegal por parte dos empregadores. Sua existência é caracterizada pela ausência de políticas públicas, miséria (subemprego-analfabetismo), expectativa de impunidade e ganância dos empregadores, precarização, entre tantos outros.

SILVA, Rute Mikaele Pachedo da. O TRABALHO ESCRAVO NO BRASIL E A EMENDA CONSTITUCIONAL Nº. 81/2014, 2016, p. 72. Trabalho de Conclusão de Curso (Mestrado em Direito). Universidade Federal de Pernambuco, 2016 [Orientador: Adriano Nascimento Silva].

8 SCHWARZ, Rodrigo Garcia. TERRA DE TRABALHO, TERRA DE NEGÓCIO: o trabalho escravo contemporâneo na perspectiva (da violação) dos direitos sociais. São Paulo, 2014, p. 138. 
Em virtude de diversas situações constatadas, ainda na década de 90 foi que o Estado brasileiro viu a necessidade de apresentar medidas efetivas de erradicação do trabalho escravo, observando a dignidade humana do trabalhador como base da liberdade, da justiça e da paz (ONU, 1948) e, ainda, como apoio para cessar o trabalho em condições análogas à de escravo contemporâneo, como na ideia de Mauricio Godinho Delgado, que diz:

O princípio da dignidade da pessoa humana traduz a ideia de que o valor central das sociedades, do Direito e do Estado contemporâneos é a pessoa humana, em sua singeleza, independentemente de seu status econômico, social ou intelectual. O princípio defende a centralidade da ordem juspolítica e social em torno do ser humano, subordinante dos demais princípios, regras, medidas e condutas. Trata-se do princípio maior do Direito Constitucional contemporâneo, espraiando-se, com grande intensidade, no que tange à valorização do trabalho (DELGADO, 2007, p. 75).

É com base na evolução dos direitos sociais dos trabalhadores e, ainda, na ideia de que a dignidade humana pressupõe que ninguém faça parte de uma relação de trabalho forçado podendo ter anulada a sua autonomia, que surgem os novos conceitos de trabalho escravo, referindo-se às diversas formas ilegais de exploração da mão de obra dos trabalhadores submetidos a essas condições, e, ainda, a necessidade de fiscalização intensa, a partir das denúncias realizadas, a fim de que se tenha a continuidade da busca pela erradicação da exposição de trabalhadores brasileiros ao trabalho em condições análogas à de escravo no Brasil.

\section{A ADMinistração PÚbliCA E O EXERCíCIO DO PODER DE POLÍCIA}

Marcelo Alexandrino e Vicente Paulo descrevem o Direito Administrativo como "o ramo do direito público que rege a organização e o exercício de atividades do Estado voltadas para a satisfação de interesses públicos". ${ }^{9}$ Relatam, ainda, que:

O Direito Administrativo possui como objeto abranger todas as relações internas à administração pública, relações entre administração e administrados, regidas predominantemente pelo direito público ou pelo direito privado, bem como atividades da administração pública em sentido material exercidas por particulares sob o regime de direito público (MARCELO ALEXANDRINO E VICENTE PAULO, 2008, p. 4).

Nessa mesma linha, os autores definem o direito administrativo como:

[...] conjunto de regras e princípios aplicáveis à estruturação e ao funcionamento das pessoas e órgãos integrantes da administração pública, às relações entre esta e seus agentes, ao exercício da função administrativa, especialmente às relações com os administradores, e à gestão dos bens públicos, tendo em conta a finalidade geral de bem entender ao interesse público (MARCELO ALEXANDRINO E VICENTE PAULO, 2008, p. 4).

9 ALEXANDRINO, Marcelo. PAULO, Vicente. Resumo de direito administrativo descomplicado. Método, 8. ed. 
Maria Sylvia Zanella Di Pietro traz em sua obra "Direito Administrativo", a sua formação, como ramo autônomo, ${ }^{10} \mathrm{com}$ a chegada do direito constitucional e outros ramos do direito público, a datar do início do desenvolvimento do Estado de Direito, assegurando a submissão às Leis e a proteção dos direitos individuais, incluindo os vínculos estabelecidos entre os cidadãos e o Estado. Ainda, descreve Di Pietro que "foi graças à elaboração jurisprudencial do Conselho do Estado Francês que se construiu o Direito Administrativo", 11 esclarecendo que o Direito Administrativo brasileiro sempre se inspirou no direito estrangeiro, inspiração esta que se mantém nos dias de hoje.

Nas palavras de Di Pietro, o papel do Direito Administrativo é considerado como: “[...] é o Direito Administrativo que rege as relações jurídicas que nascem da ação da Administração, fixa suas prerrogativas e obrigações, rege as garantias outorgadas aos particulares contra o arbítrio". ${ }^{12}$

E, ainda, estabelece o seu conceito, afirmando que:

[...] Direito Administrativo como o conjunto de princípios e normas que, sob a Constituição, têm por objeto a organização e o exercício das atividades do Estado destinadas à satisfação concreta e imediata dos interesses públicos, mediante atos jurídicos tipificados pela autoexecutoriedade, de caráter provisório, posto que sujeitos ao controle jurisdicional de legalidade (DI PIETRO, 2018, p. 113).

A partir dessas definições, temos que o Direito Administrativo e, mais precisamente a Administração Pública, tem o objetivo de controlar e fiscalizar a relação do Estado com a sociedade, a fim de proporcionar adequado controle nos vínculos provocados a partir de diversas situações. E, partindo da ideia de que a Administração Pública possui a responsabilidade de zelar pelo bem-estar dos cidadãos que dela dependem, tem-se a necessidade de fiscalização de tais situações. Logo, cabe ao Poder de Polícia o compromisso de supervisionar e controlar ocorrências que necessitem da sua intervenção.

Com a finalidade de assegurar a ordem pública e a manutenção do Estado de bem-estar é que se incumbe à Administração Pública o condicionamento do exercício daqueles direitos ao bem-estar coletivo, necessitando, dessa forma, da utilização do Poder de Polícia para a organização desse "confronto". ${ }^{13}$

No que se refere ao Poder de Polícia, o seu conceito está apontado no Código Tributário Nacional, em seu artigo 78, que afirma, nestes termos: ${ }^{14}$

Artigo 78. Considera-se poder de polícia atividade da administração pública que, limitando ou disciplinando direito, interêsse ou liberdade, regula a prática de ato ou abstenção de fato, em razão de intêresse público concernente à segurança, à higiene, à ordem, aos costumes, à disciplina da produção e do mercado, ao exercício de atividades econômicas dependentes de concessão

10 DI PIETRO, Maria Sylvia Zanella, DIREITO ADMINISTRATIVO, 31. ed. Rio de Janeiro: Forense, 2018, p. 2.

11 IDEM, p. 4.

12 DI PIETRO, Maria Sylvia Zanella, DIREITO ADMINISTRATIVO, 31. ed. Rio de Janeiro: Forense, 2018, p. 40.

13 IDEM, p. 192.

14 Lei no ${ }^{\circ}$. 5.172, de 25.10.1966. 
ou autorização do Poder Público, à tranqüilidade pública ou ao respeito à propriedade e aos direitos individuais ou coletivos.

Parágrafo único. Considera-se regular o exercício do poder de polícia quando desempenhado pelo órgão competente nos limites da lei aplicável, com observância do processo legal e, tratando-se de atividade que a lei tenha como discricionária, sem abuso ou desvio de poder.

No entendimento de Celso Antônio Bandeira de Mello, temos a definição do Poder de Polícia Administrativa, que afirma:

[...] pode-se definir a polícia administrativa como a atividade da Administração Pública, expressa em atos normativos ou concretos, de condicionar, com fundamento em sua supremacia geral e na forma da lei, a liberdade e a propriedade dos indivíduos, mediante ação ora fiscalizadora, ora preventiva, ora repressiva, impondo coercitivamente aos particulares um dever de abstenção ("non facere") a fim de conformar-lhes os comportamentos aos interesses sociais consagrados no sistema normativo (MELLO, 2005).

Como visto no artigo 78 do CTN, a definição de Poder de Polícia está na proteção do interesse público, no que diz respeito à limitação de atividades consideradas antissociais que coloquem em risco a vida de todos os cidadãos. $\mathrm{O}$ seu surgimento se fez necessário a partir da necessidade de ordenar o convívio da sociedade e, ainda, a partir da expansão dos direitos individuais e sociais, com o objetivo de preservar a estrutura social dos povos e a existência do próprio Estado. ${ }^{15}$ Em outras palavras, a intervenção do Poder de Polícia administrativa está em gerir a vida privada do cidadão, em busca do bem comum.

Hely Lopes Meirelles assegura que:

Poder de Polícia é a faculdade que dispõe a Administração Pública para condicionar e restringir o uso, o gozo de bens, atividades e direitos individuais, em benefício da coletividade ou do próprio Estado. O Poder de Polícia é o mecanismo de frenagem de que dispõe a Administração Pública para conter os abusos do direito individual (MEIRELLES, 1999, p. 115).

No entendimento de Hernán Alejandro Olano García (2010, p. 110), temos que:

[...] el poder de policía "permite tomar decisiones, de carácter general o individual, tendientes al mantenimiento del orden público o a su restablecimiento; el mando del personal de policía hace relación a la organización y la jerarquía en el cuerpo policial. Los alcaldes, por ejemplo, son jefes superiores de policía, pero no poseen, de ordinario, el mando de las fuerzas de policía, ya que las órdenes que impartan deben comunicarlas a través del respectivo comando".

Para Fernando Garrido Falla, ${ }^{16}$ o Poder de Polícia não é somente limitar as atividades particulares, como também o uso da força para com aqueles que não se conformam com tais limitações, como descreve in verbis:

15 MEIRELLES, Hely Lopes. DIREITO MUNICIPAL BRASILEIRO, 12. ed. São Paulo: Malheiros Editores, 2001, p. 440.

16 FALLA, Fernando Garrido. Las transformaciones del concepto jurídico de policía administrativa. Catedrático de derecho administrativo, 1953, p. 15. 
La policía no es, pues, solamente una posible limitación de la ¡actividad del particular, sino que implica también el posible uso de la coacción cuando el particular no se lia conformado a esas limitaciones. Para el Derecho administrativo clásico la uülización posible «le tales medio» extraordinarios se ha explicado en razón de la finalidad propia y específica que, dentro del fin genérico de utilidad pública que condiciona toda la actividad administrativa, persigue la policía. Esa "finalidad peculiar de la policía es el orden ¡iúblico" (FALLA, p. 15).

É importante frisar que embora o Poder de Polícia seja de extrema importância nas relações entre o Estado e o cidadão, os limites devem ser impostos a fim de que se mantenha o equilíbrio nos vínculos estabelecidos nas sociedades e, ainda, para que a Lei seja aplicada de forma adequada, sem violar os direitos constitucionais da pessoa humana.

É sob essa ótica que Caio $\operatorname{Tacito}^{17}(1952$, p. 9) diz:

\begin{abstract}
A faculdade de agir outorgada ao administrador não é construída no vácuo, mas em função de determinados objetivos sociais, que não podem ser ignorados ou subvertidos pelo agente. Não é lícito à autoridade pública atuar senão para o fim previsto na lei. A substituição do interêsse público especificamente considerado na regra de competência por um interêsse privado ou por outro interêsse público estranho à finalidade legal vicia, irremediàvelmente, $\mathrm{o}$ ato administrativo pela figura do desvio de poder (détournement de pouvoir).
\end{abstract}

Considerando que o Poder de Polícia seja essencialmente preventivo, fiscalizador e repressivo e, ainda, que os meios de ação administrativa exercidos pelo Poder de Polícia sejam discricionários quanto à oportunidade ou conveniência das medidas administrativas impostas, a autoridade não deve abrir mão da utilização de meios compatíveis com a Lei para exercer suas ações de fiscalização e combate de atividades que violem a legislação e o bem-estar dos cidadãos ou, até mesmo, do Estado como um todo. ${ }^{18}$

Salienta-se que o Poder de Polícia se demonstra por meio de atos administrativos que visam disciplinar o modo de atuação das autoridades administrativas, permitindo ou limitando a atividade privada, bem como. determinando condutas individuais ${ }^{19}$ que estejam interferindo na vida de cidadãos de maneira prejudicial, direta ou indiretamente, afetando o seu convívio com a sociedade em que vivem, entre outras tantas formas graves de prejudicar a qualidade de vida da pessoa humana que possui o direito de proteção pela Constituição Federal de 1988.

\title{
2.1 A Participação da administração pública na fiscalização do trabalho escravo no Brasil e sua eficácia
}

A Declaração Universal dos Direitos Humanos de 1948 prevê em seu artigo IV que "ninguém será mantido em escravidão ou servidão; a escravidão e o tráfico de escravos serão proibidos em todas as suas formas".

7 TACITO, Caio. O PODER DE POLÍCIA E SEUS LIMITES, 1952, p. 9.

18 TACITO, Caio. O PODER DE POLÍCIA E SEUS LIMITES, 1952, p. 9.

19 IDEM, p. 11. 
A Instrução Normativa Intersecretarial $n^{\circ}$. 1, de 1994, fixa os procedimentos de inspeção do trabalho em área rural e preceitua um conjunto de estratégias às Delegacias Regionais do Trabalho para a realização de ações fiscais especificamente em áreas rurais, com o propósito de identificar e colaborar na seleção de estabelecimentos a serem inspecionados. ${ }^{20}$ A primeira declaração oficial sobre a existência do trabalho escravo contemporâneo foi decretada em 1995, por meio da Portaria $n^{\circ} .550$, de 14 de junho de $1995,{ }^{21}$ e outorgava ao Grupo Especial de Fiscalização Móvel (GEFM), composto por auditores-fiscais do trabalho, agentes da Polícia Federal e procuradores do Ministério Público do Trabalho, a competência para apurar as denúncias de exploração do trabalho em condições análogas à de escravo no meio rural. ${ }^{22}$

Nessa época, em operações que confirmavam a ocorrência de trabalho escravo, os trabalhadores eram libertados e assistidos e, ainda, seus empregadores recebiam multas, além de serem obrigados a realizar o pagamento de salários, encargos e despesas de transporte devidos aos seus empregados. ${ }^{23}$

As modificações nas normas foram propostas ao longo do processo de institucionalização, com o objetivo de regulamentar o conceito de trabalho escravo contemporâneo à medida que a política pública se desenvolvia. Porém, o arranjo administrativo constituído para dar corpo à política de fiscalização do trabalho escravo era escasso, sobretudo a partir de 2003, quando o governo federal comprometeu-se a encaminhar medidas de precaução que constituem "mudanças legislativas, medidas de fiscalização e repressão do trabalho escravo no Brasil, além de medidas de sensibilização e informação da sociedade acerca do problema" (OIT, 2010, p. 29).

O Plano Nacional da Erradicação do Trabalho Escravo, lançado em 2003, é, sem dúvidas, considerado um avanço no processo de erradicação das formas análogas às da escravidão, consideradas quando houver trabalho forçado, com a manutenção do trabalhador submisso ao local de trabalho, não podendo dele afastar-se, além de condições degradantes, em casos sem possibilidades mínimas de segurança, higiene e conforto nos locais de trabalho configurando desprezo à dignidade da pessoa humana. Há ainda a jornada exaustiva de trabalho equivalente ao excesso brutal de jornada que gera desgaste físico ou mental do trabalhador, e a servidão por dívida que mantém o empregado honrado preso em seu local de trabalho por acreditar que está devendo para o seu empregador, situação que se transforma em coação moral, psicológica e truck system ${ }^{24}$ - bem como, salários pagos com base em utilidades, como comidas, vestimentas ou medicamentos (DETRAE/MTE, 2010). Além disso, o plano possuía como uma de suas propostas o aperfeiçoamento da estrutura

20

Instrução Normativa Intersecretarial, n. 1, 28 de março de 1994. DIÁRIO OFICIAL DA UNIÃO, Brasília, 1994.

21 Portaria $\mathrm{n}^{\circ} .550,14$ de junho de 1995.

22 GONÇALVES, Vera Olimpia. DADOS DO GRUPO ESPECIAL DE FISCALIZAÇÃO MÓVEL, 2000, p. 67. Brasília.

23 Eduardo Paulon Girardi, Neli Aparecida de Mello-Théry, Hervé Théry e Julio Hato, "Mapeamento do trabalho escravo contemporâneo no Brasil: dinâmicas recentes", Espaço e Economia [On-line], 4 | 2014, posto on-line no dia 11 setembro 2014, consulta em 21 outubro 2019. URL: http://journals.openedition.org/ espacoeconomia/804; DOI : 10.4000/espacoeconomia.804

24 SILVA, Renata Cristina Moreira da. O QUE SE ENTENDE POR "TRUCK SYSTEM" NO DIREITO DO TRABALHO? Disponível em: http://ww3.lfg.com.br/public html/article.php?story=20091001215417503. 
logística dos grupos de fiscalização móvel e a instalação de varas itinerantes da Justiça do Trabalho e de Delegacias do Trabalho em determinados locais com frequente prática de exploração de trabalho escravo. ${ }^{25}$

Desde que o plano foi colocado em prática, vários resgates foram realizados, com o intuito de erradicar a exploração do trabalho em condições análogas à de escravo. A fiscalização executada pela Administração Pública, no exercício do Poder de Polícia localizou, de lá para cá, diversos trabalhadores em situação de escravidão contemporânea e, ainda, muitos empregadores tiveram seus nomes inscritos na "lista suja", proveniente da Portaria $540 / 2004,{ }^{26}$ pela prática da exploração da mão de obra de seus empregados, deixando-os em situação de escravidão.

Foram muitos trabalhadores resgatados em condições análogas às de escravo. Forças tarefas e o resgate humanitário realizado pela Administração Pública, nas operações executadas pelo Poder de Polícia e diversos órgãos responsáveis, libertaram inúmeros empregados expostos às situações escravagistas, que relataram em muitas situações não possuir cama para dormir, utensílios para a manutenção de higiene e maus-tratos. Em um dos depoimentos, ${ }^{27}$ um dos trabalhadores alega que:

Lá no alojamento, temos apenas um banheiro para 45 trabalhadores. Quando fica ocupado por muito tempo, eu uso a vegetação local para mijar e defecar. Tomo banho com a água do poço, perto do alojamento, com a ajuda de um balde. Também uso a água do poço para beber e lavar roupa. O poço fica aberto o dia todo, porque a tampa de concreto é muito pesada (Anônimo).

Em outro caso relatado, ${ }^{28} \mathrm{o}$ empregado conta como está sendo obrigado a permanecer no local de trabalho desde que seu empregador reteve seus documentos:

Todos os meus documentos foram entregues quando vim da Bahia. Estou pedindo para que ele me devolva os documentos tem meses. Tenho vontade de ir embora. As condições de trabalho e de vida são ruins. Já pedi várias vezes para ir embora, mas ele promete me levar de volta e nunca cumpre. Só não fui embora porque estou sem meus documentos e não tenho dinheiro. Quero voltar para casa (Anônimo).

A existência de trabalhadores em condições análogas a de escravo em seus locais de trabalho é mais comum do que se pode imaginar, e a fiscalização é realizada de forma intensa pelos órgãos responsáveis. No demonstrativo a seguir, podemos identificar os locais com maior recorrência de tais situações, bem como, as características de trabalhadores expostos às condições de escravidão, entre os anos de 2016 e 2017, vejamos:

No Estado de Minas Gerais há o maior número de resgates de pessoas encontradas expostas às condições de escravidão no trabalho. ${ }^{29}$

\footnotetext{
25 Alexandre Arbex, Marcelo Galiza, Tiago Oliveira. A POLÍTICA DE COMBATE AO TRABALHO ESCRAVO NO PERÍODO RECENTE, 2018, p. 115.

26 Portaria $n^{\circ} .540 / 2004$.

27 Clara Valesco, Gabriela Caesar e Thiago Reis, G1. ESCRAVOS SEM CORRENTES: trabalhadores resgatados relatam ameaças, moradias insalubres e água dividida com animais, 2018. Disponível em: <g1.globo. com/economia/notícias/escravos-sem-correntes.ghtml> Acesso em: 10/2019.

28 IDEM.

29 Fonte: Comissão Pastoral da Terra.
} 
Ainda, há grande diferença entre os perfis dos trabalhadores expostos às condições de trabalho escravo contemporâneo, dominada pela classe masculina.

No que se refere à escolaridade, os trabalhadores não possuem ensino fundamental completo, tampouco ensino de qualidade. Os analfabetos representam muitos dos empregados condicionados à escravidão nos locais de trabalho. ${ }^{30}$

A faixa etária dos trabalhadores também é revelada, observando que jovens ficam mais expostos às condições análogas de escravo no trabalho, ${ }^{31}$ conforme se percebe no gráfico a seguir:

É importante frisar que entre os anos de 2016 e 2017 foram realizadas 117 operações resgate em todo o país, totalizando 1.122 pessoas libertadas de ambientes de trabalho que as deixavam em condições de escravidão e 153 estão em cerceamento de liberdade, totalizando $14 \%$ dos empregados resgatados. Além disso, 3.683 autos de infração foram lavrados e 19 autos aplicados nos casos em que houve resgate. ${ }^{32}$

\section{A implantação da Portaria 1.129/2017, de Michel Temer}

A fiscalização do trabalho escravo se dá a partir de denúncias realizadas junto aos órgãos do Poder Público, como a CONATRAE - Comissão Nacional pela Erradicação do Trabalho Escravo, DETRAE - Divisão de Fiscalização para a Erradicação do Trabalho Escravo, MPF - Ministério Público Federal e MPT - Ministério Público do Trabalho liderado pela CONAETE - Coordenadoria Nacional para Erradicação do Trabalho Escravo, no exercício do Auditor-Fiscal, que lidam, além de tudo, com as dificuldades de erradicar a execução da exploração da mão de obra em condições análogas às de escravo. O controle de tais condutas feitas pelos empregadores é exercido com base na legislação vigente, que prevê e descreve como norteadores do trabalho em condições de escravidão contemporânea situações como trabalho forçado, que obriga o trabalhador a permanecer no local de trabalho e não deixá-lo de forma espontânea, condições degradantes que rejeitam condições mínimas de segurança, higiene e conforto nos locais de trabalho (este conceito não está descrito em lei, e configura desprezo à dignidade humana), jornada exaustiva de trabalho, com o excesso brutal da força dos empregados que geram desgastes físicos e mentais. Nesse caso, temos como exemplo claro trabalhadores que realizam o corte de cana em sol escaldante e que chegam ao cansaço extremo.

Além das condições já descritas, ainda é característica do trabalho escravo a servidão por dívida, em situações que o empregador faz mau uso da boa-fé dos empregados para fazê-los crer que devem valores aos seus patrões e, dessa forma, mantê-los no local de trabalho. Nesses casos, há a coação moral e psicológica e o salário dos trabalhadores é pago com base em comidas e demais utilidades. ${ }^{33}$ Percebe-se que são diversas as situações que

30 IDEM.

31 Fonte: Comissão Pastoral da Terra.

32 Fonte: Ministério do Trabalho.

33 Luiz Fernando Calegari, Jus.com. A Portaria n. 1.129/2017 dp MT e o retrocesso no combate à escravidão contemporânea, 2017. Disponível em: <https://jus.com.br/artigos/61250/a-portaria-n-1-129-2017-dp-mt-e-o-retrocesso-no-combate-a-escravidao-contemporanea> Acesso em: 10/2019. 
caracterizam o trabalho em condições análogas às de escravo contemporâneo, e todas elas ferem a liberdade e a dignidade da pessoa humana.

Ainda assim, em 16 de outubro de 2017 foi publicada no Diário Oficial da União a Portaria $n^{\circ} .1 .127$, que trazia alterações significantes na fiscalização e erradicação do trabalho escravo contemporâneo. Entre as suas alterações na tentativa de combater a exploração do trabalho em condições análogas às de escravo, uma das mudanças mais impactantes se teve a partir da anulação das "condições degradantes" como um dos elementos que configuravam o trabalho como em condições de escravidão. ${ }^{34}$

A alteração se deu a partir da determinação de que tal condição só seria considerada como elemento para caracterizar o trabalho escravo, se sobrevinda com o cerceamento de liberdade do trabalhador. Além disso, a Portaria dificultou os mecanismos de fiscalização e erradicação do trabalho escravo condicionando à aprovação do Ministro do Trabalho a inscrição de empregadores na "lista suja", o que termina por reduzir o número de empregados regatados das condições de escravidão contemporânea. ${ }^{35}$

Outra significante alteração criada pela Portaria 1.129/17 refere-se ao direito do trabalhador resgatado das condições de escravidão de receber o benefício do seguro-desemprego, com o aumento de diversos "empecilhos" criados a partir da modificação da Lei, ${ }^{36}$ conforme vejamos:

Artigo $1^{\circ}$. Para fins de concessão de benefício de seguro-desemprego ao trabalhador que vier a ser identificado como submetido a regime de trabalho forçado ou reduzido a condição análoga à de escravo, nos termos da Portaria MTE $n^{\circ}$ 1.153, de 13 de outubro de 2003, em decorrência de fiscalização do Ministério do Trabalho, bem como para inclusão do nome de empregadores no Cadastro de Empregadores que tenham submetido trabalhadores à condição análoga à de escravo, estabelecido pela PI MTPS/MMIRDH n ${ }^{\circ} 4$, de 11.05.2016, considerar-se-á:

I - trabalho forçado: aquele exercido sem o consentimento por parte do trabalhador e que lhe retire a possibilidade de expressar sua vontade;

II - jornada exaustiva: a submissão do trabalhador, contra a sua vontade e com privação do direito de ir e vir, a trabalho fora dos ditames legais aplicáveis a sua categoria;

III - condição degradante: caracterizada por atos comissivos de violação dos direitos fundamentais da pessoa do trabalhador, consubstanciados no cerceamento da liberdade de ir e vir, seja por meios morais ou físicos, e que impliquem na privação da sua dignidade (grifos do autor).

É possível perceber que em cada condição para obter o direito do recebimento do benefício de seguro-desemprego, o trabalhador identificado em condições de escravidão contemporânea necessitaria, impreterivelmente, estar submetido ao impedimento do direito de ir e vir, com restrição de locomoção e vigilância ostensiva e sem o consentimento do

\footnotetext{
34 Portaria 1.129/17.

35 Luiz Fernando Calegari, Jus.com. A Portaria n. 1.129/2017 dp MT e o retrocesso no combate à escravidão contemporânea, 2017. Disponível em: <https://jus.com.br/artigos/61250/a-portaria-n-1-129-2017-dp-mt-e-o-retrocesso-no-combate-a-escravidao-contemporanea> Acesso em: 10/2019.

36 Portaria 1.129/17.
} 
empregado, contexto este muito específico, ainda que esteja exposto a qualquer uma das situações que o caracterizariam como um trabalhador exposto em condições análogas às de escravo.

Além disso, a Portaria 1.129/17 ainda traz novos conceitos para as situações consideradas como trabalho escravo contemporâneo, como podemos observar nos incisos já especificados, quando restou determinado que o trabalho forçado devesse estar ligado à falta de consentimento do trabalhador para ser considerado como exploração do trabalho em condições de escravidão, conforme o inciso I: ${ }^{37}$

I - trabalho forçado: aquele exercido sem o consentimento por parte do trabalhador e que lhe retire a possibilidade de expressar sua vontade (grifos do autor).

Ainda, e para que as situações de jornada exaustiva e condições de trabalho degradantes pudessem ser consideradas como exploração de trabalho escravo, a partir da alteração feita na Portaria 1.129/17, o trabalhador deve, imperiosamente, estar impedido de desfrutar o seu direito de ir e vir, não bastando apenas detectar o excesso brutal da jornada de trabalho ou a menor condição de higiene, segurança e conforto nos locais de trabalho, conforme se observa nos incisos II e III: ${ }^{38}$

II - jornada exaustiva: a submissão do trabalhador, contra a sua vontade e com privação do direito de ir e vir, a trabalho fora dos ditames legais aplicáveis a sua categoria;

III - condição degradante: caracterizada por atos comissivos de violação dos direitos fundamentais da pessoa do trabalhador, consubstanciados no cerceamento da liberdade de ir e vir, seja por meios morais ou físicos, e que impliquem na privação da sua dignidade (grifos do autor).

Outra alteração polêmica a ser destacada se refere ao cadastro dos empregadores na chamada "lista suja", onde se encontram as empresas e empresários que executam a exploração da mão de obra e deixam seus empregados em condições análogas às de escravo.

Artigo $4^{\circ}$., $\S 3^{\circ}$. Para o recebimento do processo pelo órgão julgador, o Auditor-Fiscal do Trabalho deverá promover a juntada dos seguintes documentos:

I - Relatório de Fiscalização assinado pelo grupo responsável pela fiscalização em que foi identificada a prática de trabalho forçado, jornada exaustiva, condições degradantes ou condições análogas à escravidão, detalhando o objeto da fiscalização e contendo, obrigatoriamente, registro fotográfico da ação e identificação dos envolvidos no local;

II - Boletim de Ocorrência lavrado pela autoridade policial que participou da fiscalização;

III - Comprovação de recebimento do Relatório de Fiscalização pelo empregador autuado;

IV - Envio de ofício à Delegacia de Polícia Federal competente comunicando o fato para fins de instauração.

37 Portaria 1.129/17.

38 IDEM. 
É importante frisar que as alterações já mencionadas no artigo dificultam e criam empecilhos no cadastro do empregador, cuja ação do Auditor-Fiscal tenha identificado trabalhadores submetidos às condições análogas às de escravo. ${ }^{39} \mathrm{~A}$ exigência de registros fotográficos e Boletim de Ocorrência e a expressa autorização do titular do Ministério do Trabalho dificultariam a punição de quem explora o trabalho escravo no Brasil. ${ }^{40}$

De fato, as alterações na Lei de fiscalização do trabalho escravo proveniente da Portaria 1.129/17 dificultaram a execução do controle e combate ao trabalho em condições análogas às de escravo. A erradicação da escravidão veio a sofrer com o retrocesso e as barreiras criadas, que impossibilitariam a identificação de trabalhadores expostos às situações de escravidão contemporânea em seus locais de trabalho. Com a grande repercussão gerada e a enxurrada de críticas feitas por especialistas, inclusive a Secretária Nacional da Cidadania, Flávia Piovesan, que considerou as alterações feitas pelo então Presidente Michel Temer como um "retrocesso inaceitável"41 viu-se a necessidade de impedir tamanha crueldade com os trabalhadores brasileiros, e o espantoso impacto gerado nas ações de fiscalização e erradicação do trabalho em condições análogas às de escravo contemporâneo.

\subsection{Os impactos provocados na fiscalização do trabalho escravo no Bra- sil contemporâneo}

Com a implantação da Portaria 1.129/17, houve uma enxurrada de críticas contra as alterações advindas com a nova Lei. Em entrevista para a BBC, a Secretária Nacional de Cidadania, Flávia Piovesan, declarou-se "perplexa" com as mudanças sofridas. Alegou ainda que "[...] é inaceitável e que temos que lutar pela revogação dessa portaria em caráter de urgência, porque realmente os danos são acentuados, as violações de direitos são gravíssimas". ${ }^{42}$ Tratando-se de modificações que são contrárias à Constituição Federal e ao Código Penal, a Portaria 1.129/17 foi duramente criticada por especialistas que entenderam que a sua aplicação se daria em restrição da definição de escravidão, dificultando, na prática, a libertação de trabalhadores explorados e submetidos às condições análogas às de escravo contemporâneo nos locais de trabalho. ${ }^{43}$ Ao ser questionada sobre a Portaria 1.129/17 e o novo "modelo" de combate ao trabalho em condições análogas às de escravo, a Secretária Flávia Piovesan afirma: ${ }^{44}$

Fiquei perplexa e surpresa com a publicação da portaria. Na condição de secretária nacional da Cidadania e, sobretudo na condição de presidente da CONATRAE, queria expressar minha profunda preocupação com essa portaria porque ela simboliza retrocessos inaceitáveis na luta pela prevenção, erradicação e fiscalização do trabalho escravo. Lamentavelmente, fomos todos aqui da CONATRAE e da secretaria surpreendidos.

39 Portaria 1.129/17.

40 IDEM.

${ }^{41}$ Mariana Schreiber, BBC Brasil. Secretária de Temer diz que mudança no combate ao trabaho escravo é 'retrocesso inaceitável', 2017. Disponível em: https://bbc.com/portuguese/brasil-41660080. Acesso em: $8 / 2019$.

42 Mariana Schreiber, BBC Brasil. Secretária de Temer diz que mudança no combate ao trabalho escravo é 'retrocesso inaceitável', 2017. Disponível em: https://bbc.com/portuguese/brasil-41660080. Acesso em: $8 / 2019$.

43 IDEM.

44 IDEM. 
É importante frisar que, no ano de 2016, o Brasil foi condenado pela Corte Interamericana de Direitos Humanos no caso da fazenda Brasil Verde, quando dois trabalhadores passaram três dias na mata até encontrar refúgio e conseguir denunciar o proprietário da fazenda que mantinha seus trabalhadores em condições de escravidão. Este foi o primeiro caso sobre escravidão e tráfico de pessoas decidido pela corte, com repercussão mundial, e o Estado Brasileiro, por ser conivente com o trabalho escravo realizado na fazenda, foi condenado a indenizar os 128 trabalhadores encontrados e resgatados das condições trágicas de escravidão. ${ }^{45}$

Desde então, a luta pela erradicação do trabalho em condições análogas às de escravo no Brasil aumentou, com a intensa fiscalização e resgate de trabalhadores expostos às condições de trabalho escravo contemporâneo. Tentando minimizar os efeitos da Portaria, o então presidente Michel Temer alegou que diversos autos de infração recebidos pelo Ministro do Trabalho eram insignificantes para considerar como situações de trabalho escravo, criticando supostos excessos na fiscalização, o que, segundo ele, justificaria as críticas sofridas. ${ }^{46}$ Com a implantação da Portaria 1.129/17 e a torrente de críticas, o Partido Rede Sustentabilidade ingressou com uma denúncia de inconstitucionalidade que foi analisada e julgada pela Ministra Rosa Weber e obteve progresso.

$\mathrm{Na}$ ADPF 489, a discussão se refere a:

[...] ao praticamente inviabilizar o combate ao trabalho escravo no país, a Portaria atacada descumpre os preceitos fundamentais da Constituição da República concernentes à dignidade da pessoa humana (art. $1^{\circ}$., III), aos objetivos fundamentais da República de 'construir uma sociedade justa e solidária' (art. $3^{\circ}$., I), 'erradicar a pobreza e a marginalização e reduzir as desigualdades sociais e regionais' (art. $3^{\circ}$., III) e 'promover o bem de todos, sem preconceitos de origem, raça, sexo, cor, idade e quaisquer outras formas de discriminação' (art. $3^{\circ}$., III) [...] (ADPF 489) (grifos do autor).

Ainda, a ADPF 489 traz a discussão de que as lesões sofridas pelas alterações provenientes da Portaria 1.129/17 ferem os princípios da moralidade administrativa e da impessoalidade, na medida em que o ato não aprimora o combate ao trabalho escravo e sim, impede as ações penais que devem ser aplicadas nos casos em que ficar evidenciadas a prática de exploração da mão de obra escrava. ${ }^{47}$

Considera, ainda: "[...] como um dos mais graves problemas sociais do país, e a consequente vulneração da dignidade humana e dos direitos fundamentais de incontáveis indivíduos [...] (ADPF 489, p. 4)".

A Ministra Rosa Weber, em sua análise quanto à Portaria 1.129/17, alega que:

$\mathrm{O}$ ato de privar alguém de sua liberdade e de sua dignidade, tratando-o como coisa e não como pessoa humana, é repudiado pela ordem constitucional, quer

45 IDEM.

46 Hellen Guimarães, Lupa. Temer minimiza efeitos da nova Portaria sobre o trabalho escravo. 2017. Disponível em: https:/cbn.globorario.globo.com/media/audio/131361/checagem-lupa-cbn-temer-minimiza-efeitos-da-nova-p.htm. Acesso em: 11/2019.

47 ADPF 489, p. 4. 
se faça mediante coação, quer pela violação intensa e persistente de seus direitos básicos, inclusive do direito ao trabalho digno (ADPF 489, p. 8).

Considerando a violação do direito ao trabalho digno, a Ministra esclarece que "o impacto na capacidade da vítima de realizar escolhas segundo a sua livre determinação, também significa "reduzir alguém a condição análoga à de escravo". ${ }^{48}$ Por esse motivo, a Ministra afirma:

\begin{abstract}
Por evidente, não é qualquer violação dos direitos trabalhistas que configura trabalho escravo. Se, no entanto, a afronta aos direitos assegurados pela legislação regente do trabalho é intensa e persistente, se atinge níveis gritantes e se submetidos os trabalhadores a trabalhos forçados, jornadas exaustivas ou a condições degradantes, com a privação de sua liberdade e de sua dignidade, resulta configurada, mesmo na ausência de coação direta contra a liberdade de ir e vir, hipótese de sujeição de trabalhadores a tratamento análogo ao de escravos [...] (ADPF 489, p. 8) (grifos do autor).
\end{abstract}

Fica evidente a desconformidade da Portaria 1.129/17 quando, ao analisar os conceitos apresentados, a Ministra concluiu que:

[...] a Portaria do Ministério do Trabalho $n^{\circ}$. 1.129/2017 ora adota conceitos tecnicamente frágeis, ora impõe a concatenação de hipóteses quando, à luz do ordenamento jurídico vigente, a presença de cada um deles já seria suficiente [...] (ADPF 489, p. 9).

Dessa forma, restaram evidentes as dificuldades impostas pela Portaria, com a imposição da privação do direito de ir e vir para caracterizar trabalho em condição análoga à de escravo, dificultando as operações de fiscalização realizadas na busca pela erradicação do trabalho escravo contemporâneo. E, ainda, a Ministra entende como:

[...] alterações empreendidas nos procedimentos administrativos configuram quadro normativo de aparente retrocesso no campo da fiscalização e da sanção administrativa, como técnica de prevenção e promoção da erradicação do trabalho escravo, de modo a dificultar a política pública de combate ao trabalho escravo (ADPF 489, p. 12) (grifos do autor).

Ao entender que a nova moldura normativa advinda com a Portaria 1.129/2017 "contesta a trajetória jurídica e administrativa realizada pelo Brasil nos últimos vinte anos no sentido de combate à escravidão contemporânea", vulnera os princípios basilares da Constituição Federal de 1988 e não protege de forma suficiente os direitos fundamentais nela assegurados, promovendo um grande descompasso em relação aos compromissos internacionais assumidos pelo Brasil, ${ }^{49}$ decidiu-se pela suspensão da Portaria 1.129/2017, bem como, de todos os seus efeitos para a manutenção do combate ao trabalho em condições análogas às de escravo contemporâneo.

\footnotetext{
48 ADPF 489, p. 8.

49 ADPF 489, p. 19.
} 
Após a decisão de suspensão da Portaria 1.129/2017, a Administração Pública, em 28 de dezembro de 2017, implantou nova portaria que devolvia à fiscalização do trabalho escravo a conformidade com as leis, a sua constitucionalidade, possuindo o objetivo de manter a liberdade e a dignidade da pessoa humana. A nova Portaria vigente, 1.293/2017, restabelece não somente o conceito de trabalho escravo, como ainda, resgata a maneira constitucional de caracterizar a exploração da mão de obra em condições análogas às de escravo. A primeira grande alteração promovida pela nova Portaria, 1.293/2017, teve relação com o conceito de trabalho escravo, bem como, com a sua consequência para o recebimento do benefício de Seguro-Desemprego, conforme vejamos:

Artigo $1^{\circ}$. - Para fins de concessão de benefício de seguro-desemprego ao trabalhador que for encontrado em condição análoga à de escravo no curso de fiscalização do Ministério do Trabalho, nos termos da Portaria MTE $n^{\circ} 1.153$, de 13 de outubro de 2003, bem como para inclusão de administrados no Cadastro de Empregadores que tenham submetido trabalhadores à condição análoga à de escravo, estabelecido pela Portaria Interministerial MTPS/MMIRDH n ${ }^{\circ} 4$, de 11 de maio de 2016, considera-se em condição análoga à de escravo o trabalhador submetido, de forma isolada ou conjuntamente, a:

I- Trabalho forçado;

II - Jornada exaustiva;

III - Condição degradante de trabalho;

IV - Restrição, por qualquer meio, de locomoção em razão de dívida contraída com empregador ou preposto, no momento da contratação ou no curso do contrato de trabalho;

V - Retenção no local de trabalho em razão de:

a) Cerceamento do uso de qualquer meio de transporte;

b) Manutenção de vigilância ostensiva;

c) Apoderamento de documentos ou objetos pessoais.

(Portaria 1.293/2017) (grifos do autor).

Nota-se que as alterações feitas pela Portaria 1.293/2017 devolvem o antigo conceito de trabalho escravo contemporâneo e, ainda, ampliam suas características, que na norma anterior estavam todas ligadas a determinadas condições. Com as mudanças empreendidas, há extensão das condições que caracterizam o trabalho em condições análogas às de escravo, assim como a liberdade e facilidade dos órgãos fiscalizadores em localizar e punir os locais que fazem o uso da prática da exploração da mão de obra em condições de escravidão contemporânea.

Ainda, e com relação à inscrição de empregadores na já citada lista suja, quando na portaria antiga criou-se uma série de empecilhos que dificultavam na ação do Auditor-Fiscal para a fiscalização e erradicação do trabalho em condições análogas às de escravo, a nova Portaria devolve a facilidade de combater e punir os empregadores que exercem a exploração da mão de obra escrava, como é possível observar:

Artigo $3^{\circ}$. - Os conceitos estabelecidos no artigo $2^{\circ}$. desta norma deverão ser observados pelo Auditor-Fiscal do Trabalho em qualquer ação fiscal direcionada para erradicação do trabalho em condição análoga à de escravo ou em ações fiscais em que for identificada condição análoga à de escravo, indepen- 
dentemente da atividade laboral, seja o trabalhador nacional ou estrangeiro, inclusive quando envolver a exploração de trabalho doméstico ou de trabalho sexual, bem como para fins de inclusão de registro no Cadastro de Empregadores que tenham submetido trabalhadores à condição análoga à de escravo estabelecido pela Portaria Interministerial MTPS/MMIRDH nº. 4/2016 (Portaria $1.293 / 2017)$.

É com base nas alterações mencionadas que podemos perceber o retrocesso obtido com a implantação da Portaria 1.129/2017 e o quão importante foi a sua repercussão que veio a ocasionar, na discussão realizada na ADPF 489 da Ministra Rosa Weber, a sua suspensão e revogação. A implantação da nova Portaria 1.293/2017 alcançou méritos extremos por devolver à Administração Pública e ao Poder de Polícia a eficácia na fiscalização e no combate à erradicação da exploração do trabalho em condições análogas às de escravo no Brasil contemporâneo.

\section{CONSIDERAÇões FINAIS}

O trabalho escravo possui suas origens nos anos de 1500 e 1600, no Brasil, com a utilização de pessoas humildes para o trabalho pesado e nenhuma recompensa. Sem qualquer assistência, pessoas eram escravizadas e não ganhavam absolutamente nada em troca e, ainda, sem a menor chance de um futuro digno, muitas delas não resistiam, e morriam nas mãos de seus "senhores".

Com o passar dos anos e a partir da luta pela erradicação da escravização de pessoas, após a implantação da Lei Áurea, ficou expressamente impedida a prática escravagista exercida em qualquer circunstância. Ainda assim, e mesmo com a sua proibição, muitas pessoas são submetidas a tais práticas, por serem consideradas como as mais vulneráveis. Desde jovens até os mais velhos, homens e mulheres com escolaridade baixa ou nenhuma formação, que não possuem renda, tampouco condições de sobrevivência, se submetem às condições impostas por seus empregadores, acreditando que podem construir um futuro melhor para si e sua família.

Órgãos criados para o combate ao trabalho escravo contemporâneo atuam arduamente nas denúncias feitas, com o intuito de fiscalizar e erradicar a exploração da mão de obra escrava. Nessa linha, a Administração Pública, no papel do Poder de Polícia, possui o dever de fiscalizar os locais denunciados e, quando constatada a prática de exploração da mão de obra em condições análogas às de escravo, resgatar os trabalhadores assim expostos, libertando-os e punindo os empregadores que estão fazendo o uso de tal prática. Os números nos mostram a realidade da existência da exploração de trabalhadores expostos dia após dia às condições de trabalho escravo, na atualidade.

Ainda, e com toda a operação exercida para erradicar o trabalho em condições análogas às de escravo, a alteração da Lei, advinda da Portaria 1.129/2017 trouxe, além da enxurrada de críticas, o retrocesso no combate ao trabalho escravo contemporâneo ao descaracterizar as condições que determinavam as práticas de trabalho em condições de escravidão. Com tamanha repercussão e a necessária suspensão da Portaria 1.129/2017, percebe-se o quão forte é a luta pela erradicação do trabalho escravo contemporâneo e a busca constante pela 
liberdade e dignidade da pessoa humana, a fim de exterminar por completo as desigualdades entre as pessoas e, principalmente, entre empregado e empregador, trazendo, além de justiça às minorias, condições dignas de trabalho para empregados brasileiros que estão em busca de um futuro.

Finalmente, com a nova Portaria 1.293/2017, cabe ao Poder de Polícia, regido pela Administração Pública, dar continuidade à fiscalização e combater a exploração da mão de obra em condições análogas às de escravo no nosso Brasil contemporâneo.

\section{REFERÊNCIAS}

. ADPF 489 de 2017.

. Constituição da República, de 5/10/1988.

. Instrução Normativa Intersecretarial, n. 1, 28 de março de 1994. DIÁRIO OFICIAL DA UNIÃO, Brasília, 1994.

. Lei 2.848, de 7/12/1940.

Lei n. 5.172, de 25.10.1966.

. Organização Internacional do Trabalho (OIT), 2010.

. Organização das Nações Unidas (ONU), 1948.

. Portaria n. 550, 14 de junho de 1995.

. Portaria n. 540/2004.

. Portaria n. 1.129/2017.

Portaria n. 1.293/2017.

ALEXANDRINO, Marcelo. VICENTE, Paulo. Resumo de direito administrativo descomplicado. Método, 8. ed.

ARBEX, Alexandre, GALIZA, Marcelo, OLIVEIRA, Tiago. A política de combate ao trabalho escravo no período recente, 2018.

BENCI, Jorge. Economia cristã dos senhores no governo dos escravos. Mendes, São Paulo: Grijalbo, 1977.

CALEGARI, Luiz Fernando, Jus.com. A Portaria n. 1.129/2017 dp MT e o retrocesso no combate à escravidão contemporânea, 2017. Disponível em: $<\underline{\text { https://jus.com.br/arti- }}$ gos/61250/a-portaria-n-1-129-2017-dp-mt-e-o-retrocesso-no-combate-a-escravidao-contemporanea> Acesso em: 10/2019. 
CHALHOUB, Sidney. A força da escravidão, 1957. São Paulo: Companhia das Letras, ed. 2015.

Comissão Pastoral da Terra. Disponível em: <https://www.cptnacional.org.br/>. Acesso em: 9/2019.

DE ASSIS, Machado. Conto Pai contra mãe, 1906.

DELGADO, Mauricio Godinho. Direitos Fundamentais na Relação de Trabalho. In: SILVA, Alessandro da; MAIOR, Jorge Luiz Souto; FELIPE, Kenarik Boujikian; SEMER, Marcelo (Coord.). Direitos Humanos: essência do Direito do Trabalho. São Paulo: Ed. LTr, 2007.

DI PIETRO, Maria Sylvia Zanella, Direito Administrativo, 31. ed. Rio de Janeiro: Forense, 2018.

FALLA, Fernando Garrido. Las transformaciones del concepto jurídico de policía administrativa. Catedrático de derecho administrativo, 1953.

GARCÍA, Hernán Alejandro Olano. La policía administrativa. Artículos de revisión, 2010.

GIRARDI, Eduardo Paulon; MELLO-THÉRY, Aparecida de, THÉRY, Hervé e HATO, Julio, "Mapeamento do trabalho escravo contemporâneo no Brasil: dinâmicas recentes", Espaço e Economia [On-line], 4 | 2014, posto on-line em 11 setembro 2014, consulta em 21 outubro 2019. Disponível em: http://journals.openedition.org/espacoeconomia/804; DOI: 10.4000/espacoeconomia.804.

GONÇALVES, Vera Olimpia. Dados do grupo especial de fiscalização móvel, 2000. Brasília.

GUIMARÃES LUPA, Hellen. Temer minimiza efeitos da nova Portaria sobre o trabalho escravo, 2017. Disponível em: https://cbn.globorario.globo.com/media/audio/131361/ checagem-lupa-cbn-temer-minimiza-efeitos-da-nova-p.htm. Acesso em: 11/2019.

JUNIOR, José Cretella. Do poder de polícia. Forense: São Paulo, 1999.

LOPES, Alberto Pereira. Escravidão por dívidas no Norte dos Estados do Tocantins: vidas fora de compasso. Tese de Doutorado em Geografia Humana. São Paulo: FFLCH-USP, 2009.

MEIRELLES, Hely Lopes. Direito municipal brasileiro, 12. ed. São Paulo: Malheiros Editores, 2001.

OLIVEIRA, Regiane, El País. Eram escravos no Brasil e não sabiam. Agora o mundo todo ficou sabendo, 2017. Disponível em: https://brasil.elpais.com/brasil/2016/12/17/economia/1481988865_894992.html. Acesso em: 11/2019. 
SCHREIBER, Mariana, BBC Brasil. Secretária de Temer diz que mudança no combate ao trabalho escravo é 'retrocesso inaceitável', 2017. Disponível em: https://bbc.com/ portuguese/brasil-41660080. Acesso em: 8/2019.

SCHWARZ, Rodrigo Garcia. Terra de trabalho, terra de negócio: o trabalho escravo contemporâneo na perspectiva (da violação) dos direitos sociais. LTr Digital: São Paulo, 2014.

SILVA, Renata Cristina Moreira da. O que se entende por "truck system" no direito do trabalho? Disponível em: <http://ww3.lfg.com.br/public_html/article.php?story $=20091001215417503>$.

SILVA, Rute Mikaele Pachedo da. O trabalho escravo n Brasil e a Emenda Constitucional n. 81/2014, 2016. Trabalho de Conclusão de Curso (Mestrado em Direito). Universidade Federal de Pernambuco, 2016 [Orientador: Adriano Nascimento Silva].

TÁCITO, Caio. Poder de polícia e seus limites. Revista de Direito Administrativo, Rio de Janeiro, 1952.

VAINFAS, Ronaldo. Ideologia e escravidão. Os letrados e a sociedade escravista no Brasil Colonial. Vozes: Petrópolis, 1986.

VALESCO, Clara, CAESAR, Gabriela e REIS, Thiago, G1. Escravos sem correntes: trabalhadores resgatados relatam ameaças, moradias insalubres e água dividida com animais, 2018. Disponível em: <g1.globo.om/economia/notícias/escravos-sem-correntes.ghtml> Acesso em: 10/2019.

\section{Carine Azevedo Saraiva}

Graduanda em Direito pela Universidade Lasalle. E-mail: carineazevedo.s@hotmail.com

Submetido em: 14-10-2020

Aceito em: 7-11-2020 